\title{
Neogene Climate, Terrestrial Mammals and Flora of the Indian Subcontinent
}

\author{
RAJEEV PATNAIK ${ }^{1, *}$ and VANDANA PRASAD ${ }^{2}$ \\ ${ }^{1}$ Center for Advanced Study in Geology, Panjab University, Chandigarh, India \\ ${ }^{2}$ Birbal Sahni Institute of Palaeosciences, Lucknow, India
}

(Received on 10 April 2016; Accepted on 28 April 2016)

\begin{abstract}
The present review compiles the work done in and around India during 2011-2015 on the terrestrial climate, fauna and vegetation changes during the Neogene. Tectonics that led to the final closure of Tethys, uplift of the Tibetan plateau, land connection between Africa and Eurasia played a major role in the climatic variability and paleobiogeographic history of fauna and flora of the Indian subcontinent. Though the timing of initiation of monsoon is still a debatable issue, establishment of seasonal reversal in wind direction pattern during summer and winter period and development of monsoonal climate in larger parts of the Indian subcontionent is characteristic of Neogene. Fossil records of flora and fauna provide evidence of warm and humid climate of early Neogene, which then shifted to cooler and drier conditions during the late Neogene. This shift in the climatic conditions resulted in a major vegetation change in the Indian subcontinent with Early and Middle Miocene being dominated by $\mathrm{C}_{3}$ vegetation, and warm and humid tropical flora in low land areas while Late Miocene and Pliocene saw the dominance of $\mathrm{C}_{4}$ grasslands. Influenced by this major vegetation and ecological shift around Late Miocene, several browsing mammals of the Early and Middle Miocene landscape gave way to mostly grazing mammals of the Late Miocene and Pliocene time.
\end{abstract}

Key words: Indian Subcontinent; Neogene; Mammalia; Vegetation; Dispersal; Paleobiogeography

\section{Introduction}

Being part of the Oriental Biogeographic Province the fauna and flora of India have evolved under an essentially monsoonal climatic condition during much of the Neogene. The Neogene climate was influenced by several factors that include suturing of the Indian and Asian plates, uplift of the Himalayas, change in the ocean current directions and northern hemisphere glaciations. Overall, the Early Neogene witnessed a warm and humid condition followed by a rather cooler and drier regime during the later stages.

The present review compiles the work done in the Indian subcontinent in the last five years on Neogene terrestrial fauna and flora and their relation to the overall Neogene climate change. The Neogene faunal sites of India are primarily located in the Siwalik fluvial deposits that stretches from Pakistan in the west to Assam in the North East exposed all along the Himalayan foothills (Fig. 1). However, Early Miocene fossils are also known from the TransHimalayan Kargil Molasse Group and foreland basin Murree Formation and its equivalents the Dharamsala, Dagshai and Kasauli Formations. In the peninsular India, Middle and Late Miocene mammals are known from the Kutch basin (Bhandari et al., 2015). In the North East of India, Garo Hills represent a Middle Miocene Locality (Patnaik, 2016 and references therein). The localities in the peninsula that can be assigned a Late Miocene age are Perim Islands (Patnaik, 2016 for a review) in the west and Baripada Beds (Sharma and Patnaik, 2013) and Tripura in the east.

\section{Early Miocene ( 23 to $\sim 16$ Ma) Fauna and Vegetation}

Early Neogene fluvio-deltaic sediments are exposed in Trans Himalayas (ex. Kargil deposits), Himalayan

\footnotetext{
*Author for Correspondence: E-mail: rajeevpatnaik@gmail.com
} 


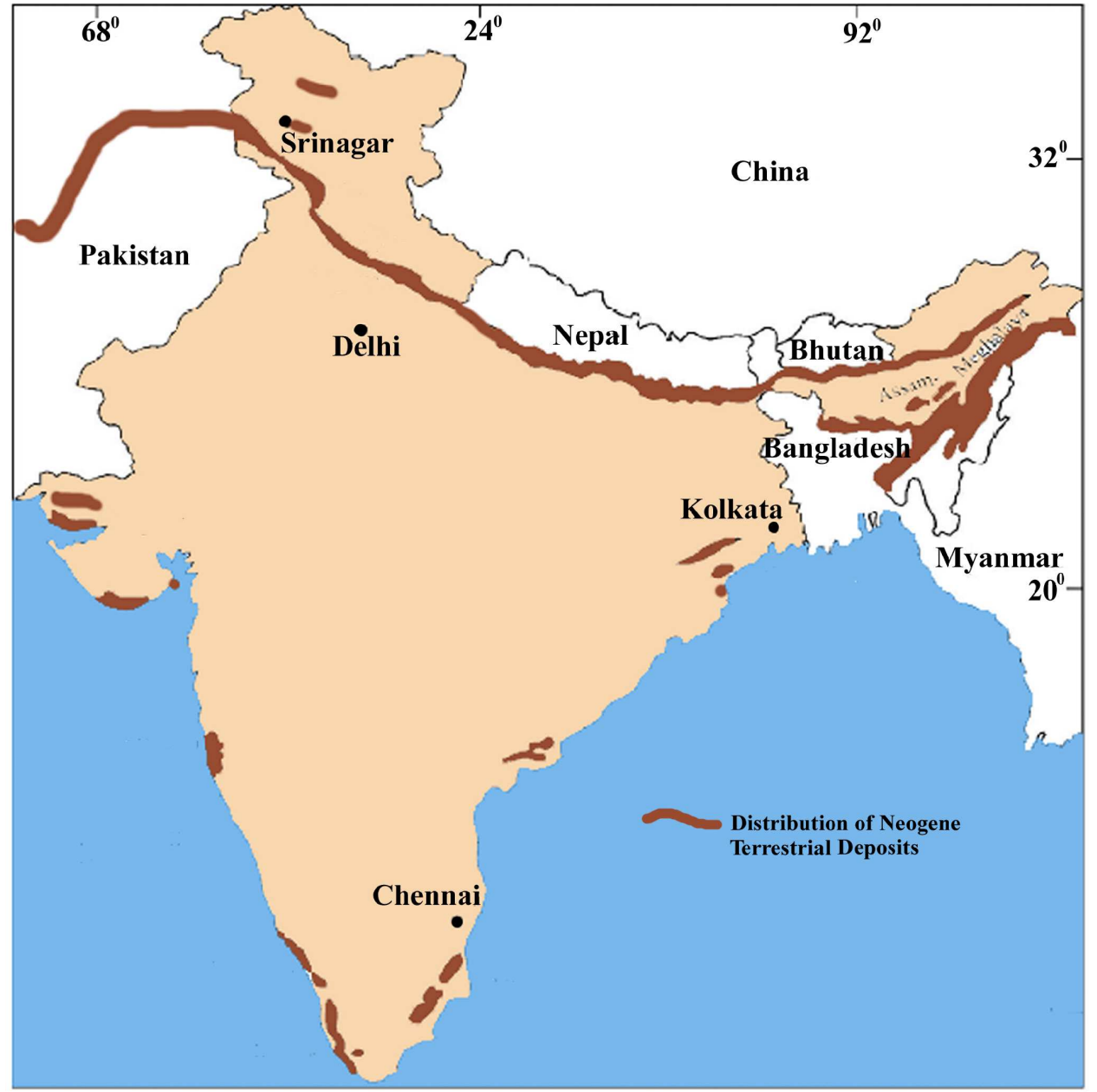

Fig. 1: Map of India and neighbouring countries showing the distribution of terrestrial Neogene deposits

foreland basin (ex. Murrees) and Sulaiman Province of Pakistan. In the Bugti and Zinda Pir Dome areas of Pakistan these fluvio-deltaic deposits have yielded a wide variety of fossil mammals (Antoine et al., 2013). From the Kargil deposits Late Oligocene to Early Miocene rodents and ungulates similar to those occurring in the Bugti and Zinda Pir areas are found (Prasad et al., 2005; Patnaik, 2016 for a review).

The foreland deposits referred to as the Murree Group are best recorded from the Murree Hills of Pakistan and Jammu and Kashmir region in India. Their equivalent in Kangra, Himachal Pradesh, are referred to as the Dharamsala Group, and in the Simla region as the Dagshai (lower sequence) and Kasauli Formations.

Kargil Molasse have yielded the artiodactyl and the rodent Democricetodon assignable to early
Miocene following the occurrence of the anthracothere Sivameryx at Bugti and Zinda Pir Hills, from $\sim 22$ to $\sim 18 \mathrm{Ma}$ (Antoine et al., 2013) and at Potwar from 17.8 to $15.6 \mathrm{Ma}$ (Barry et al., 2013).

Kargil molasse deposits have yielded remains of palms Sabal, Tachycarpus, Amesoneuron and Palmacites. Guleria et al. (1983) reported Prunnus from the Liyan Formation (equivalent to Kargil Molasse).The early Miocene plant mega fossils of Kasauli Formation predominantly consists of tropical evergreen to moist deciduous species that include Ficus, Chukrasia, Garcinia, Gluta, Kayea, Mallotus, Mesua, Persea and Phyllanthus (Srivastava et al., 2014 and reference therein). Dipterocarpus fossil wood in the Kasaulis, as well as fossil fruits from Early Miocene sediments of Kutch, Gujarat, comparable to Shorea macroptera Dyer of the Malayan Peninsula (Shukla et al., 2012), suggest 
that the family Dipterocarpaceae might have arrived from the southeast Asia in the early Miocene (Tiwari et al., 2012). Contrary to this, the pollen record from western India indicates its existence since the Early Eocene (Dutta et al., 2011; Rust et al., 2010). The Kasauli Formation has also yielded algal, fungal and pteridophytic spores, gymnospermous and angiospermous pollen indicating presence of a moist subtropical climate with some montane elements (Rao and Verma, 2014 and reference therein). Fossils of Dipterocarpaceae are known from late Early/Middle Miocene of Kutch and other sites in Gujarat and Rajasthan (Shukla et al., 2012). In another study, two fossil woods, namely Bauhinium palaeomalabaricum (Fabaceae) and Ebenoxylon indicum (Ebenaceae), described from early Miocene of Kutch suggest a warm and humid climate with good rainfall during early Miocene in the region (Shukla et al., 2015).

The Murree/Dharamsala Group, of Himalayan foreland basin contain Deinotherium sp. Teleoceras (Brachypotherium) fatehjangense, Palaeochoerus sp. (Conohyus) and Microbunodon sp. and Gonotelma sp. and can be correlated well with early Miocene of Upper Chitarwata Formation and lowest Vihowa Formation in the Bugti Hills (Welcomme et al., 2001; Antoine et al., 2010; 2013). Kumar and Kad (2003) reported a cricetid, Primus microps from Kalakot (Jammu and Kashmir) and opined that the Murree sediments of India are of Early Miocene age. Prodeinotherium from the Upper Dharamsala beds of Kangra Valley may also indicate Early Miocene age (Tiwari et al., 2006; Flynn et al., 2013).

The diverse faunal assemblage from Kutch, Gujarat includes Deinotherium sindiense, Gomphotherium indet., Brachypotherium sp., Parabrachyodus hyopotamoides, Sivameryx palaeindicus, Conohyus sindiensis/Tetraconodon malensis, Libycochoerus fategadensis, Giraffokeryx punjabiensis and Dorcatherium minus (Bhandari et al. 2010; Patnaik et al., 2014). The age of the mammal fauna from Tapar and Pasuda sections of Kutch, described previously by Bhandari et al. (2010), has now been revised to basal Late Miocene ( 11-10 Ma) based on the presence of Hipparion (Bhandari et al. 2015). Bhandari et al. (2015) also discovered a maxilla of a chimpanzee-sized sivapithecine hominoid from these deposits making it the first such find from peninsular India. A new fossil suid Kachchhchoerus salinus has also been described by these authors.

\section{Middle Miocene ( 16 to $\sim 11.5$ Ma) Fauna and Vegetation}

The Middle Miocene Siwalik vegetation predominantly consists of evergreen and some moist deciduous elements (Srivastava et al., 2014). The evergreen elements include Bouea, Bursera, Calophyllum, Dipterocaprus, Garcinia, Hopea, Kayea, Polyalthia, Saccopetalum tomentosum, Shorea and Swintonia (Srivastava et al., 2014 and references therein). These taxa are found today in high rainfall regions either in the Western Ghats or in northeast India (Srivastava et al., 2014). A good number of plant megafossils in the form of woods and leaves were described from Middle Siwaliks of Nalagarh and Jawalamukhi (Prasad, 2006). Middle Siwalik pollens and spores include Cyathidites, Alsophilidites, Leptolepidites, Podocarpidites, Pinuspollenites, Monoporopollenites, Alnipollenites and Tetradomonoporites (Rao and Verma, 2014 and references therein).

The typical Chinji lithology (Type area in Pakistan) of red beds occur around the famous primate yielding locality of Ramnagar. The mammalian fauna represents $\sim 14$ to $12 \mathrm{Ma}$ (Sehgal and Patnaik, 2012; Parmar et al., 2015). Ramnagar assemblage is very similar to the Chinji fauna and include rodents: Kanisamys cf. potwarensis, Antemus chinjiensis, Megacricetodon cf. sivalensis and Sivacanthion complicates; primates: Sivaladapis palaeindicus, Sivapithecus sivalensis, S. indicus and S. simonsi; creodont: Dissopsalis carnifex; carnivores: Eomellivora necrophila, Vishnuonyx chinjiensis, Amphicyon sp., Percrocuta carnifex, Viverra chinjiensis, and Vishnufelis sp.;perissodactyls: cf. Caementodon sp. Aceratherium perimense, Gaindatherium browni, Brachypotherium sp., Chilotherium? intermedium, Chalicotherium sp.; proboscideans: Deinoitherium pentapotamiae, Prodeinotherium sp., Gomphotherium sp. and Tetralophodon sp.;suids:

Hippopotamodon haydeni, Conohyus chinjiensis, C. sindiense, Listriodon pentapotamiae, Propotamochoerus sp. and Sus sp; anthracotheres Anthracotherium punjabiense 
(=Microbunodon silistrensis) and Hemimeryx pusillus (= Merycopotamus pussilus) (Lihaeroau et al., 2004); tragulids: Dorcabune anthracotherioides, D. nagrii, Dorcatherium majus, D. minus and D. Nagrii; Pecora: Progiraffa;giraffids: Giraffa priscilla and Giraffokeryx punjabiensis; bovids: Helicoportax, Gazella and Kubanotragus (Patnaik, 2016 and references therein). Recent addition to the rodent fauna include Megacricetodon daamsi, Megacricetodon sivalensis and Myocricetodon sivalensis (Parmar et al., 2015). In the northeast the Garo Hills, Assam have yielded Microbunodon silistrensis suggesting a late early Miocene (17.8 Ma) to middle Miocene (11.4 Ma) age (Patnaik, 2016 and references therein).

\section{Late Miocene (11-5.5 Ma) Fauna and Vegetation}

During the Late Miocene the global climate entered a phase of cooler and drier conditions. A sudden rise of the Himalayas and intensification of the Asian monsoons were mainly responsible for an overall change in the vegetation towards the dominance of C4 grasslands in the Indian subcontinent. The sedimentary environment of the Indian foreland also changed leading to the development of southward shifting inter-fan river system that replaced the large emergent rivers.

The floral assemblage of Middle Siwaliks of Nepal show presence of subtropical and temperate forests with high altitude taxa such as Abies, Larix and Picea (Hoorn et al., 2000). Middle Siwaliks exposed near Haridwar have yielded Diospyros belonging to Ebenaceae, Homonoia and Croton of Euphorbiaceae, Albizia, Cassia, Dalbergia and Pongamia of the Fabaceae, Swietenia of the Meliaceae, Myrsine of the Myrsinaceae, Eucalyptus of the Myrtaceae and Zizyphus of the Rhamnaceae families (Prasad and Khare, 1994).

The magnetostratigraphycally dated Late Miocene Haritalyangar locality has yielded primates: Indopithecus, Sivapithecus, Indraloris, Sivaladapis and Pliopithecus (Patnaik, 2013 and references therein). The mammals that appear for the first time during this period include: Parapelomys, Parapodemus, Miorhizomys, Sivaonyx, Ictitherium, Enhydrodon, Tetralophodon, Choerolophodon, Stegolophodon, Anancus,
Hipparion, Propotamochoerus, Sus, Giraffokeryx, Pachyportax, Bramatherium, Selenoportax and Vishnutherium.

The Kalagarh locality, which is situated in the state of Uttarakhand has also yielded primates and other mammals. Patnaik (2013) constrained this locality between 9.3 and 8 Ma based on first and last appearances of Late Miocene mammals. Sharma and Patnaik (2014) recovered a fossil suid, namely Tetraconodon cf. intermedius from Baripada Beds exposed in the Mayurbhanj District of Orissa. Based on this find Sharma and Patnaik, (2014) place this site between 10-8 Ma.

Another well known Middle Siwalik locality is Nurpur, Himachal Pradesh that has yielded a fauna very similar to that of Haritalyangar. The Nurpur assemblage include Dissopsalis, Amphicyon, Deinoitherium, Prodeinotherium, Gomphotherium, Tetralophodon, Aceratherium, Gaindatherium, Cormohipparion, Hipparion, Hippopotamodon, Listriodon, Propotamochoerus, Anthracotherium, Merycopotamus, Dorcabune, Dorcatherium, Hydaspitherium, Giraffokeryx, Bramatherium and Protragocerus. Patnaik (2013) suggested an age bracket of 10.1-9.7 Ma to this site. Recently, Sehgal (2015) described Tetraconodon minor and several other mammals from this site and discussed the Eurasian and African affinities and in situ evolution of these mammals.

Perim Island in the gulf of Gujarat has yielded a diverse assemblage of mammals including the proboscideans Anancus perimense, Deinotherium angustidens, Gomphotherium hasnotensis, Stegolophodon cautleyi and Stegolophodon latidens: the perissodactyls Brachypotherium perimense, Aceratherium perimense and Hipparion antelopinum: the artiodactyls Dorcatherium minus, Bramatherium perimense, Antelope planicornis, Pachyportax sp. Tragoportax sp. Tragoceras perimense, Selenoportax vexillarius, Ruticeras compressa and Merycopotamus pusillus. With an improved biochronology available for the Neogene bovids and equids such as Hipparion antelopinum these deposits would be younger than 10.7 Ma. Based on the presence of Selenoportax vexillarius these sediments would range between 10.2 and $9.8 \mathrm{Ma}$ (See Patnaik, 2016). 
Bokabil Formation in Tripura is known for proboscideans Gomphotherium angustidens and Stegolophodon cautleyi: the perissodactyl Hipparion theobaldi, the artiodactyls Dorcatherium, Pachyportax sp. and Propotamochoerus hysudricus. If we follow the first and last appearance of taxa such as Hipparion and Propotamochoerus hysudricus these deposits would be at least $6.8 \mathrm{Ma}$ and at the most 10.2 Ma old (Patnaik, 2016).

\section{Pliocene ( 5.3 to 2.6 Ma) Fauna and Vegetation}

The Upper Siwaliks are characterised by thickly bedded conglomerate facies with lensoid bodies of sandstone and mudstones. However, the fine-grained facies belonging to Tatrot and Pinjor formations can be found around Jammu and Chandigarh.

The lower Pliocene Upper Siwalik sediments of Saketi area have yielded spores, gymnosperms and angiosperm pollen such as Laricoidites, Inaperturopollenites, Pinuspollenites, Pinjoriapollis and Monoporopollenite. Upper Siwalik sequence in the Haripur Khol area of Himachal Pradesh has produced pteridophytic spores of Cyathea, Pteris, Ceratopteris, Lycopodium and some Polypodiaceae spores and gymnosperms such as Pinus and Abies (Phadtare et al., 1994). The angiosperms reported by Phadtare et al. (1994) include the true grasses (Poaceae), palms (Arecaceae), lilies (Liliaceae), custard apples (Annonaceae), goosefoots (Chenopodiaceae), bombax (Bombacaceae), sunflower (Asteraceae), mallows (Malvaceae), leguminose (Mimosaceae), water lilies (Nympheaceae), milkworts (Polygalaceae), bedstraws (Rubiaceae) and carrots (Apiaceae). Phadatre et al. (1994) found 4-3.5 Ma to be dominated by dry grasslands, 3.5-2.7 Ma had muddy and marshy conditions and between 2.7 and 2.5 Ma widespread ponding conditioned developed.

The Tatrot Formation in Pakistan represents 200,000 years from 3.5 to $3.3 \mathrm{Ma}$ and has yielded Anancus falconeri, Hippohyus lydekkeri, Hippotragus and Hydaspicobus (Colbert,1935; Pilgrim, 1939). The Lower Pliocene records in India are fragmentary. It is only at Saketi, Himachal Pradesh that we get some exposures of these sediments that have yielded some mammals. The mammalian species that have been recovered from Saketi are: the leporid
Pliosiwalagus whitei, murines, Dilatomys moginandensis, Cremnomys cf. C. cutchicus, Bandicota sivalensis and Golunda tatroticus, the gerbelline Abudhabia cf. A. kabulense, elephants, Stegodon insignis, Anancus (=Pentalophodon) khetpuraliensis, the suids Hippohyus tatroti, Sivachoerus and Propotamochoerus hysudricus, the hippo, Hexaprotodon sivalensis, the giraffid, Hydaspitherium megacephalum, the equid Hipparion and the bovid Gazella.

In the Upper Pliocene sediments the Saketi region contain Suncus cf. S. murinus, Pliosiwalagus whitei, Rhizomyides saketiensis, Rhizomyides cf. R. sivalensis, Mus flynni, M. jacobsi, Parapelomys robertsi, Bandicota sivalensis, Cremnomys, Millardia, Anancus (=Pentalophodon) khetpuraliensis, Elephas planifrons, Stegodon insignis, Stegodon bombifrons, Hexaprotodon sivalensis, Sivachoerus, Hippohyus tatroti, Propotamochoerus hysudricus, Camelus sivalensis, Sivatherium giganteum, Proamphibos kashmiricus, Probison dehmi, Hydaspitherium megacephalum, Hipparion and Gazella (Patnaik, 2013; Nanda, 2013).

Upper Pliocene sediments in the Jammu region have yielded Golunda kelleri, Dilatomys pilgrimi, Rhizomyides sivalensis, Abudhabia cf. A. kabulense, Stegodon bombifrons, Hipparion antelopinum, Cormohipparion theobaldi and Propotamochoerus hysudricus (Nanda, 2013).

A morpho-taxonomic study on leaf remains of 23 species and 20 genera belonging to 15 angiosperm families recorded from the upper part of the Siwalik succession of sediments (Kimin Formation; upper Pliocene to lower Pleistocene) of Papumpare district, Arunachal Pradesh, were compared with their NLRs (Nearest Living Relatives). Among these taxa, 11 species are recorded as new to the Neogene flora of India. Analysis of the floral assemblage with respect to the distribution pattern of modern equivalent taxa and the physiognomic characters of the fossil leaves, suggests that a tropical evergreen forest was growing in a warm humid climate in the region at the time of deposition. This is in contrast to modern tropical semievergreen forests that occupy the same area. Values of mean annual temperature (MAT) of $29.3^{\circ} \mathrm{C}$ and 
mean annual precipitation (MAP) of $290 \mathrm{~mm}$ have been calculated using leaf-margin characters and fossil leaf size. The study shows that Upper Pliocene to lower Pleistocene was comparatively much more humid as compared to the Pliocene deposits of the Jammu region (Khan et al., 2011).

\section{Discussions}

Overall the Neogene faunal and vegetation changes follow the climate, tectonic and eustatic pattern. Just prior to the Neogene a cooler climate was present because of an increase in the polar ice (DeConto et al., 2008; Zachos et al., 2001).This also led to an overall drop in the sea level. The early Neogene saw an increase in temperature due to the closure of the Tethys leading to a reorganisation of ocean currents. This development culminated with the Middle Miocene Climate Optima. During this period a warm and humid condition prevailed and tropical evergreen forests covered a large part of the subcontinent. Among these were the dipterocarps, which extended from Myanmar in the east to Kutch and Kasauli in the West. By the later part of the Middle Miocene woodlands strated spreading and there is evidence of seasonality, which by the Late Miocene gets intensified and monsoonal conditions prevailed. This led to a dominance of the grasslands in place of the forests. Warm and humid conditions continued throughout the Pliocene when the landscape was dominated by wooded grasslands. The Late Pliocene saw cooler and drier conditions.

Among the mammals the Laurasiatheres which include the Artiodactyls, perissodactyls, bats, carnivores and pangolins (O'Leary et al., 2013) were already present in Eurasia in the early Neogene. In fact, perissodactyls were present on the Indian plate as early as Eocene prior to its collision with Asia (Bajpai et al., 2006; Rose et al., 2014). On the other hand the Afrotheres that includes the proboscideans, hyrocoids, and embrithopods were confined to Africa till the latest Oligocene. But around the Oligo-Miocene boundary $\sim 23 \mathrm{Ma}$ tectonics led to the suturing of Afro-Arabian and Eurasian plates. This land connection permitted Eurasian mammals to disperse into Africa and African mammals to move into Eurasia. This land connection known as the "Gomphotherium Land Bridge" facilitated African proboscideans in the early Miocene ( $20 \mathrm{Ma})$ to enter the subcontinent and also disperse into Europe and finally into North America through the Bering Strait. Taking advantage of this route Eurasian mammals such as rhinos, chalicotheres and suids dispersed into Africa between 20-18 Ma (Bernor et al., 1987; Bishop, 2010; Coombs and Cote, 2010). Among the proboscideans Prodeinotherium and Gomphotherium were the first to cross the Afro-Arabia-Eurasia land bridge and reach the Indian subcontinent. Flynn et al., 2013 proposed the First Appearance Datum of Prodeinotherium at $\sim 23 \mathrm{Ma}$, whereas Gomphotherium now occurs at $\sim 22 \mathrm{Ma}$, suggesting an earlier dispersal of these two taxa (Antoine et al., 2013 and reference therein).

The existence of tragulid Dorcatherium in Kenya and Chitarwata Formation of Pakistan may indicate an early Miocene faunal exchange between India and Africa (Antoine et al., 2013). There is good evidence of presence of south asian murid close to Potwarmus and the ctenodactylid Sayimys $\sim 18.5$ Ma in Saudi Arabia and North Africa (Flynn and Wessels, 2013 and references there in). Likewise, the rhizomyine Prokanisamys also disperses to Saudi Arabia and North Africa in the early Miocene. In the Middle Miocene rodents such as Democricetodon, Eumayrion, Sayimys and Myocricetodon are found in Anatolia suggesting migration (Flynn and Wessels, 2013). Primus and Megacricetodon of an East Asian origin entered the subcontinent in the early Miocene (Flynn et al., 2014).

Since the earliest creodonts are found in Africa, the creodonts Hyanailouros and Pterodon might have migrated from Africa to Asia at $\sim 18$ and $19.5 \mathrm{Ma}$ followed by Dissopsalis that appears for the first time in the Siwaliks at 16.1 Ma. On the other hand fossil record suggest that the carnivores migrated from Asia to Africa. One good example of this is the early record of the carinivore, Amphicyon in the earliest Miocene sediments of Bugti Hills and its later occurrence in Africa (Antoine et al., 2013). Around this time (16 Ma) the thryonomyid Kochalia also reaches Pakistan from Africa (Flynn and Winkler, 1994). The primate Dionysopithecus could be another early immigrant from Africa to the subcontinent. The anthracotheres entered Africa from Asia in the Early Miocene as well.

The Middle Miocene saw dispersal of Apes 


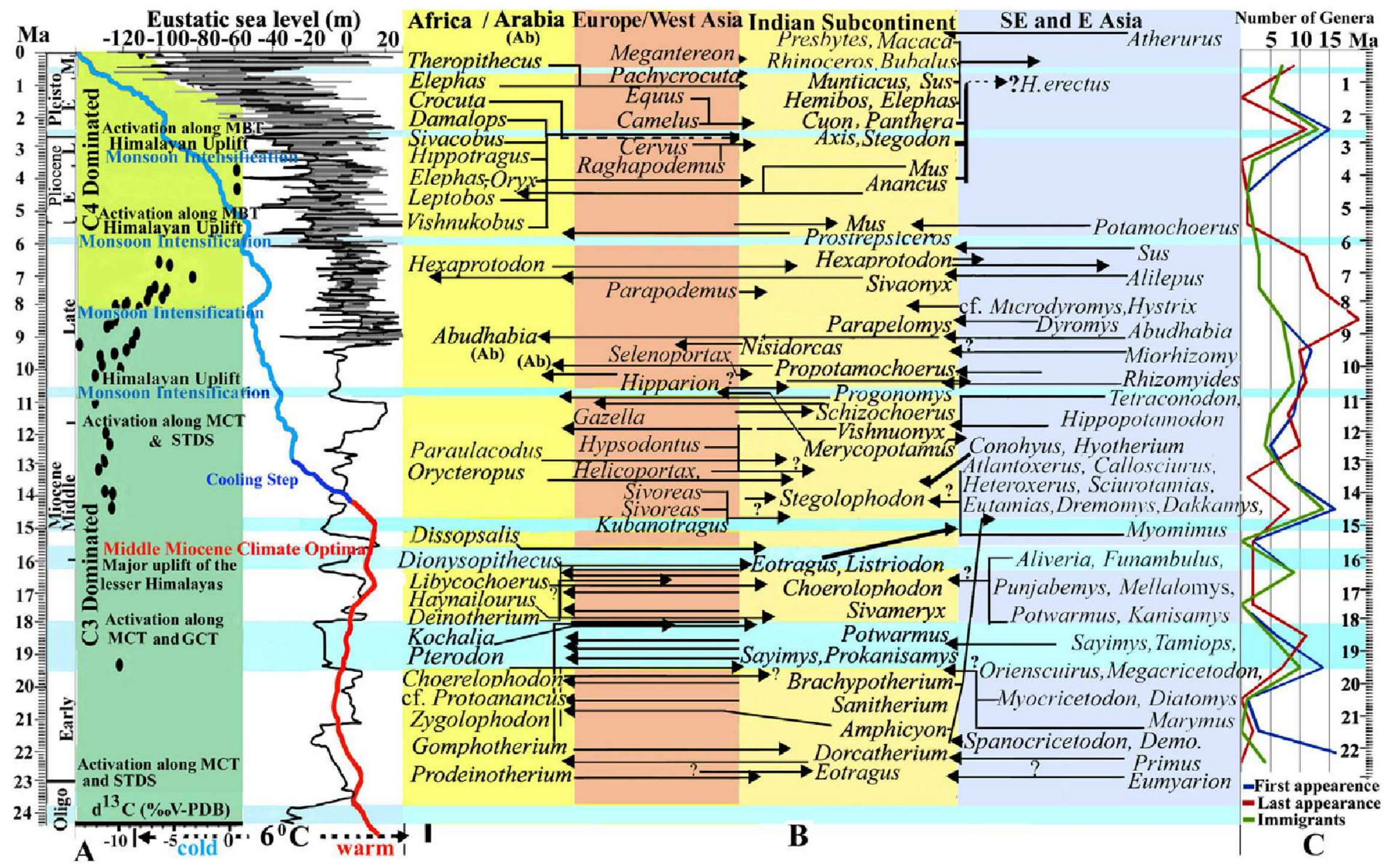

Fig. 2: A correlation between Neogene-Quaternary global temperature, sea levels and subcontinental tectonics and vegetation and mammalian faunal changes. A: Vegetation change based on mammalian enamel carbon stable isotope values (Martin et al., 2011 and references therein); eustatic sea levels (Miller et al., 2005) and temperature change (Zachos et al., 2001). B: Major dispersals of mammals to and from the Indian subcontinent. Broken lines: direction of dispersal not certain. C: Number of first and last appearances, and immigrants among the mammalian genera. Sky blue horizontal bands: Major drops in the sea level (source: Patnaik, 2016) 
prior to $16 \mathrm{Ma}$, these were not present in Eurasia. At the start of Middle Miocene, seasonal forests and woodlands expanded in both Africa and Eurasia. The early apes most likely adapted to such open conditions dispersed to Europe and then to the subcontinent. The Siwalik Miocene ape such as Sivapithecus most likely had its ancestor reaching the Indian subcontinent from the west sometime around 15-16 Ma (Begun, 2005).

During the Late Miocene the climate became cooler and drier facilitating the spread of grasslands at the expense of forests. The three toed equid Hipparion disperses from North America in the Middle Miocene arriving first in China around and then in Europe followed by in the Siwaliks at $10.7 \mathrm{Ma}$ (Barry et al., 2002). The bovid Kobus porrecticornis ranges in Pakistan from 8.1 to $7.7 \mathrm{Ma}$ (Gentry et al., 2014). Bibi (2011) found that Kobus porrecticornis indicates intercontinental dispersal as it is known from the latest Miocene of East and South Africa between 6.5 to $5 \mathrm{Ma}$. Another bovid Prostrepsiceros vinayaki ranged in the Siwaliks from 9.3-7.9 Ma, and has been recorded from Arabia around 8-6 Ma and in Africa between 5.7 and $5.4 \mathrm{Ma}$, again indicating existence of dispersal corridor in the Late Miocene (Bibi, 2011). The widespread suid Propotamochoerus hysudricus is an immigrant at $\sim 10 \mathrm{Ma}$ to the subcontinent (Flynn et al., 2014) and most probably came from China where the genus occurs in older deposits. It also occurs at Abu Dhabi sometime between 8-6 Ma (see Patnaik, 2016 and reference therein).

A faunal event known as the 'Leporid Event' happens in the late Miocene (Flynn et al., 2013). The first leporid Alilepus appears in south Asia at 7.4 Ma from North America via China and go on to disperse into Africa (Flynn et al., 2013). The porcupine Hystrix appears for the first time at $8 \mathrm{Ma}$ in south Asia arriving most likely from the east (Flynn and Wessels, 2013). The gerbil Abudhabia was widespread and is known from Late Miocene of China, Pakistan, Afghanistan, UAE, Libya and Kenya (Flynn and Wessels, 2013; Fortelius, 2013 NOWdatabase). The otter Sivaonyx was widespread too occurring in India, Pakistan, China, Thailand, Turkey and Germany during Middle to Late Miocene. It most likely dispersed to Africa in the Late Miocene (Grohe et al., 2013).
During the Early Pliocene murid rodents of south asian origin such as Mus appears in Kenya (Patnaik, 2014) where as Golunda group murids occur at Early Pliocene of Morocco and Ethiopia (Fortelius, 2013 NOW database). The hippo Hexaprotodon sivalensis and the elephant Elephas planifrons were also immigrants to the subcontinent from Africa. Camelus, Equus, Cervids and Rhagapodemus dispersed to the subcontinent in the Late Pliocene (Kotlia, 2013; Patnaik, 2016 and references therein).

Spatial variation in climate was seen during later part of Neogene. Plant records show that Late Pliocene of Arunachal Pradesh was comparatively much more humid (Khan et al., 2011) as compared to the Late Pliocene of the Jammu region.

Overall, the major dispersal events that include number of first and last appearances and immigrants, coincides with major sea-level drops (Miller et al., 2005) (Fig. 2).

\section{Conclusions}

Climate played a major role in the distribution of fauna and flora of the Indian subcontinent throughout the Neogene. Tectonics led to the closure of the Tethys followed by the collision of Africa and Eurasia, which in turn created land connections and altered the climatic and vegetation scenario of the subcontinent. Combined with this, major sea level drops allowed faunal and floral elements to disperse into and out of the subcontinent. Most of the mammalian dispersals from and to the west (Africa, Eurasia), first and last appearances took place around 20-18, 17-16, 11-10, 6-5 and 3-1 Ma. Neogene mammals appears to have followed a coastal route to disperse into the subcontinent, as most of the early Neogene sites such as Chitarwata, Kargil and Kutch have yielded coastal flora and fauna. The large mammalian data indicate that most of the migrations took place from the Africa, West Asia and Europe. However, several small mammals entered the subcontinent from Myanmar, Thailand and South China.

\section{Acknowledgements}

We would like to thank Professors A K Singhvi and $\mathrm{D} M$ Banerjee for the invitation to contribute to this volume. 


\section{References}

Antoine P O, Métais G, Orliac M, Crochet J Y, Flynn L J, Marivaux L, Rajpar A R, Roohi G and Welcomme J L (2013) Mammalian Neogene biostratigraphy of the Sulaiman Province, Pakistan. In: Wang, X, Flynn L J, Forteliu, M (Eds.), Fossil Mammals of Asia: Neogene Biostratigraphy and Chronology Columbia University Press, New York, pp 400-422

Antoine P O, Downing K F, Crochet J Y, Duranthon F, Flynn L J, Marivaux L, Métais G, Rajpar A R and Roohi G (2010) A revision of Aceratherium blanfordi Lydekker, 1884 (Mammalia: Rhinocerotidae) from the early Miocene of Pakistan: postcranials as a key Zoological Journal of the Linnean Society 160 139-194

Bajpai S, Kapur V V, Thewissen J G M, Das D P and Tiwari B N (2006) New early Eocene cambaythere (Perissodactyla, Mammalia) from the Vastan Lignite Mine (Gujarat, India) and an evaluation of cambaythere relationships Journal of the Palaeontological Society of India 51 101-110

Barry J C, Behrensmeyer A K, Badgley C E, Flynn L J, Peltonen H, Cheema I U, Pilbeam D, Lindsay E H, Raza S M, Rajpar A R and Morgan ME (2013) The Neogene Siwaliks of the Potwar Plateau, Pakistan. In: Wang X, Flynn L J, Fortelius M (Eds.), Fossil Mammals of Asia: Neogene Biostratigraphy and Chronology Columbia University Press, New York, pp 373-399

Barry J C, Morgan M E, Flynn L J, Pilbeam D, Behrensmeyer A K, Raza S M, Khan I A, Badgley C, Hicks J and Kelley J (2002) Faunal and environmental change in the late Miocene Siwaliks of northern Pakistan Paleobiology 28 1-71

Begun D R (2005) Sivapithecus is east and Dryopithecus is west, and never the twain shall meet Anthropol Sci 113 53-64

Bernor R L, Brunet M, Ginsburg L, Mein P, Pickford M, Rögl F, Sen S, Steininger F and Thomas H (1987) A consideration of some major topics concerning Old World Miocene mammalian chronology, migrations and paleogeography Geobios 20 431-439

Bhandari A, Mohabey D M, Bajpai S, Tiwari B N and Pickford M (2010) Early Miocene mammals from central Kutch (Gujarat) western India: Implications for geochronology, biogeography, eustacy and intercontinental dispersals Neues Jahrbuch Fur Geologie Palaontogie Abhandlungeh 256 69-97

Bhandari A, Pickford M and Tiwari B N (2015) Basal Late Miocene Mammal Fauna from Tapar and Pasuda, Kachchh Münchner Geowissenschaftliche Abhandlungen Reihe A: Geologie und Paläontologie 4 31-38

Bibi F (2011) Mio-Pliocene faunal exchanges and African biogeography The record of fossil bovids PLoS ONE 6:e16688

Bishop L C (2010) Suoidea In: Werdelin L and Sanders W J (Eds) Cenozoic Mammals of Africa University of California Press, Berkeley, pp 821-842

Colbert E H (1935) Siwalik mammals in the American Museum of Natural History Transactions of the American Philosophical Society 26 278-294

Coombs M C and Cote S M (2010) Chalicotheriidae In: Werdelin L and Sanders W J (Eds.) Cenozoic Mammals of Africa. University of California Press, Berkeley, pp 659-668

DeConto R M, Pollard D, Wilson PA, Palike H, Lear C H, Pagani M (2008) Thresholds for Cenozoic bipolar glaciations Nature 455 652-656

Dutta S, Tripathi S K M, Mallik M, Mathews R P, Greenwood P F, Malagalapalli R R and Summons E (2011b) Eocene out-of-India dispersal of Asian dipterocarps Review of Palaeobotany \& Palynology 116 63-68

Flynn L J, Lindsay E H, Pilbeam D, Raza S M, Morgan M E, Barry J C, Badgley C, Behrensmeyer A K, Cheema I U, Rajpar A R and Opdyke N D (2013) The Siwaliks and Neogene evolutionary biology in South Asia. In: Wang X, Flynn L J, Fortelius M (Eds.), Fossil Mammals of Asia: Neogene Biostratigraphy and Chronology. Columbia University Press, New York, pp 353-372

Flynn L J and Wessels W (2013) Paleobiogeography and South Asian Small mammals. Neogene Lattitudinal faunal Variation The Siwaliks and Neogene evolutionary biology in South Asia. In: Wang X, Flynn L J, Fortelius M (Eds.), Fossil Mammals of Asia: Neogene Biostratigraphy and Chronology. Columbia University Press, New York, pp. $445-460$

Flynn L J, Morgan M E, Pilbeam D and Barry J (2014) "Endemism" relative to space, time, and taxonomic level Annales Zoologici Fennici 51 245-258

Flynn L J and Winkler A J (1994) Dispersalist implications of Paraulacodus indicus: a South Asian rodent of African affinity Historical Biology 9 223-235

Fortelius M (2013) New and Old Worlds Database of Fossil Mammals (NOW) University of Helsinki, (http:// www.helsinki.fi/science/now/)

Gentry A W, Solounias N and Barry J C (2014) Stability in higher level taxonomy of Miocene bovid faunas of the Siwaliks Annales Zoologici Fennici 51 49-56

Guleria J S, Thakur V C, Virdi N S and Lakhanpal R N (1983) A fossil wood of Prunus from Kargil (=Liyan) Formation of Ladakh. In: Thakur, V.C., Sharma, K.K. (Eds.), Geology of Indus Suture Zone of Ladakh, WIHG, Dehradun, pp. 
$187-193$

Grohé, Camille Bonis, Louis de Chaimanee, Yaowalak, Blondel, Cécile, Jaeger and Jean-Jacques (2013) The oldest Asian Sivaonyx (Lutrinae, Mustelidae): a contribution to the evolutionary history of bunodont otters Palaeontologia Electronica 1630A 13

Hoorn C, Ohja T and Quade J (2000) Palynological evidence for vegetation development and limatic change in the SubHimalayan Zone (Neogene, Central Nepal) Palaeogeography, Palaeoclimatology, Palaeoecology 163 133-161

Khan M A, Ghosh R, Bera S, Spicer R A and Spicer T E V (2011) Floral diversity during Plio-Pleistocene Siwalik sedimentation (Kimin Formation) in Arunachal Pradesh, India and its palaeoclimatic significance Palaeobiodiversity and Palaeoenvironments (Springer Publ) 91 237-255

Kotlia B S (2013) Rhagapodemus (Rodentia, Mammalia) from the Karewas of Kashmir (India): another evidence of Pliocene faunal exchange between Europe and NW India Himalayan Geology 34 1-8

Kumar K and Kad S (2003) Early Miocene vertebrates from the Murree Group, northwest Himalaya, India affinities and age implications Himalayan Geology 24 29-53

Lihoreau F, Barry J, Blondel C and BrunetM (2004) A new species of Anthracotheriidae, Merycopotamus medioximus, nov. sp. from the Late Miocene of the Potwar Plateau, Pakistan Comptes Rendus Palevol 3 653-662

Martin C, Bentaleb I and Antoine P O (2011) Pakistan mammal tooth stable isotopes show paleoclimatic and paleoenvironmental changes since the early Oligocene Palaeogeography, Palaeoclimatology, Palaeoecology 31 19-29

Miller K G, Kominz M A, Browning J V, Wright J D, Mountain G S, Katz M E, Sugarman P J, Cramer B S, Christie-Blick N P and Stephen F (2005) The Phanerozoic Record of Global Sea-Level Change Science 310 1295-1298

Nanda A C (2013) Upper Siwalik Mammalian Faunas of the Himalayan foothills Journal of the Palaeontological Society of India $\mathbf{5 8}$ 75-86

O'Leary M A, Bloch J I, Flynn J J, Gaudin T J, Giallombardo A, Giannini N P, Goldberg S L, Kraatz B P, Luo Z X, Meng J, Ni X, Novacek M J, Perini FA, Randall Z S, Rougier G W, Sargis E J, Silcox M T, Simmons N B, Spaulding M, Velazco P M, Weksler M, Wible J R and Cirranello A L (2013) The placental mammal ancestor and the post-K-Pg radiation of placentals Science $339662-667$

Parmar V, Prasad G V R, Kumar J, Malik M A and Rigzin N (2015) Cricetid rodents from the Lower Siwalik Subgroup of Jammu, India: Biochronological Significance. Paleoworld (in press)

Patnaik R (2016) Neogene-Quaternary Mammalian Paleobiogeography of the Indian Subcontinent: An appraisal Comptes Rendus Palevol 919 1-14

Patnaik R (2013) Indian Neogene Siwalik mammalian biostratigraphy: An overview In: Wang X, Flynn L J, Fortelius M (Eds.), Fossil Mammals of Asia: Neogene Biostratigraphy and Chronology. Columbia University Press, New York, pp. 423-444

Patnaik R (2014) Phylogeny Of Siwalik Murine Rodents: Implications For Mus-Rattus Divergence Time Journal of Palaeontological Society of India 59 15-28

Patnaik R, Milankumar K, Negi S, Williams L, Kay B and Chatrath R P (2014) Additional Vertebrate Remains from the Early Miocene of Kutch, Gujarat Special Publication of The Palaeontological Society of India 5 353-365

Phadtare N R, Kumar R and Ghosh S K (1994) Stratigraphic palynology, floristic succession and the Tatrot/Pinjor boundary in Upper Siwalik sediments of Haripur Khol area, district, Sirmaur (Himachal Pradesh), India Himalayan Geology 15 69-82

Pilgrim G E (1939) The fossil Bovidae of India Palaeontologia Indica NS 26 1-356

Prasad M (2006) Plant fossils from Siwalik sediments of Himachal Pradesh and their palaeoclimatic significance Phytomorphology 56 9-22

Prasad M and Khare E G (1994) Occurrence of Dipterocarpus Gaertn. in the Siwalik sediments of Hardwar, Uttar Pradesh, India Biological Memoirs 20 51-54

Prasad G V R, Bajpai S, Singh S and Parmar V (2005) First cricetid rodent (Mammalia) from the Ladakh Molasse, Nortwestern Himalaya, India: age implications Himalayan Geology 26 85-92

Rose Kenneth D, Holbrook, Luke T. Rana, Rajendra S, Kumar, Kishor, Jones, Katrina E, Ahrens, Heather E, Missiaen, Pieter, Sahni, Ashok, Smith and Thierry (2014) Early Eocene fossils suggest that the mammalian order Perissodactyla originated in India Nature Communications 5 5570 DOI: 10.1038/ncomms6570

Rao M R and Verma P (2014) Miocene Palynology in India: Present Status and Future Prospect Special Publication of the Palaeontological Society of India 5 145-160

Rust J, Singh H, Rana R S, Mccann T, Singh L, Anderson K and Sarkar N (2010) Biogeographic and evolutionary implications of adiverse paleobiota in amber from the early Eocene of India Proceedingsof the National Academy of Sciences USA 107 18360-18365 
Sehgal R K and Patnaik R (2012) New muroid rodent and Sivapithecus dental remains from the Lower Siwalik deposits of Ramnagar (J\&K, India): Age implication Quaternary International 269 69-73

Sehgal R K (2015) Mammalian faunas from the Siwalik sediments exposed around Nurpur, District Kangra (H.P.): age and palaeobiogeographic implications Himalayan Geology 36 9-22

Sharma K Milankumar and Patnaik R (2013) Record of Late Miocene Suid, Tetraconodon intermedius from Baripada Beds (Mayurbhanj, Orissa): Age Implications Journal of Palaeontological Society of India 58 213-218

Shukla A, Mehrotra R C and Guleria J S (2013) Emergence and extinction of Dipterocarpaceae in western India with reference to climate change: Fossil wood evidences Journal Earth System Science 122 1373-1386

Shukla A, Mehrotra R C, Mandal N and Thakkar M G (2015) Two new fossil woods from the early Miocene of Kutch, Gujarat, India and their significance Historical Biology 27 970-977

Srivastava, Gaurav, Mehrotra R C, Shukla A and Tiwari R P (2014) Miocene Vegetation And Climate In Extra Peninsular India: Megafossil Evidences. Special Publication of The Palaeontological Society of India 5 283-290
Tiwari B N, Verma B C and Bhandari A (2006) Record of Prodeinotherium (Proboscidea: mammalian) from the midTertiary Dharamsala Groupof the Kangra Valley, NW Himalaya, India: Biochrologic and palaeo-geographic implications Jour Palaeontol Soc India 51 93-100

Tiwari R P, Mehrotra R C, Srivastava G and Shukla A (2012) The vegetation and climate of a Neogene petrified wood forest of Mizoram, India Journal of Asian Earth Sciences 61 $143-165$

Tiwari R P, Ralte V Z, Zoramthara C, Srivastava G, Mehrotra R C, Paul S and Dutta S (2015) Fossil Leaves in Amber from the Bhuban Formation, Mizoram, India Himalayan Geology 36 33-38

Welcomme J L, Benammi M, Crochet JY, Marivaux L, Métais G, Antoine P O and Baloch I S (2001) Himalayan Forelands: palaeontological evidence for Oligocene detrital deposits in the Bugti Hills (Balochistan, Pakistan) Geological Magazine 138 397-405

Zachos J C, Pagani M, Sloan L, Thomas E and Billups K (2001) Trends, rhythms, and aberrations in global climate $65 \mathrm{Ma}$ to present Science 292 686-693. 